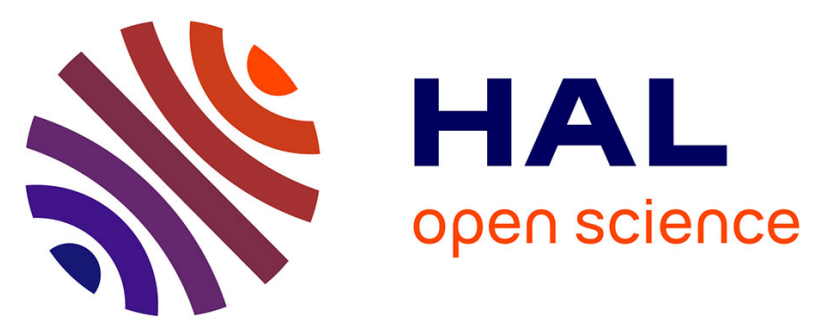

\title{
The effect of deer browsing and understory light availability on stump mortality and sprout growth capacity in sessile oak
}

Anders Mårell, Jean-Pierre Hamard, Thomas Perot, Sandrine Perret, Nathalie Korboulewsky

\section{To cite this version:}

Anders Mårell, Jean-Pierre Hamard, Thomas Perot, Sandrine Perret, Nathalie Korboulewsky. The effect of deer browsing and understory light availability on stump mortality and sprout growth capacity in sessile oak. Forest Ecology and Management, 2018, 430, pp.134-142. 10.1016/j.foreco.2018.08.015 . hal-02499909

\section{HAL Id: hal-02499909 \\ https://hal.science/hal-02499909}

Submitted on 5 Mar 2020

HAL is a multi-disciplinary open access archive for the deposit and dissemination of scientific research documents, whether they are published or not. The documents may come from teaching and research institutions in France or abroad, or from public or private research centers.
L'archive ouverte pluridisciplinaire HAL, est destinée au dépôt et à la diffusion de documents scientifiques de niveau recherche, publiés ou non, émanant des établissements d'enseignement et de recherche français ou étrangers, des laboratoires publics ou privés. 
Author-produced version of the article published in Forest Ecology and Management, 2018, 430, $134-142$

The original publication is available at : https://www.sciencedirect.com/science/article/pii/S0378112718310223

doi : 10.1016/j.foreco.2018.08.015; https://doi.org/10.1016/j.foreco.2018.08.015

(c). This manuscript version is made available under the CC-BY-NC-ND 4.0 license http://creativecommons.org/licenses/by-nc-nd/4.0/

1 Journal: Forest Ecology and Management

2 Type of article: Regular paper

3 Title: The effect of deer browsing and understory light availability on stump mortality and sprout

4 growth capacity in sessile oak

5 Version: 2018-08-06

6 Authors: Anders Mårell ${ }^{a *}$, Jean-Pierre Hamard ${ }^{a}$, Thomas Pérot ${ }^{a}$, Sandrine Perret ${ }^{a}$, Nathalie

$7 \quad$ Korboulewsky

8

9

IIrstea, UR EFNO, F-45290 Nogent-sur-Vernisson, France

10

11 E-mail: anders.marell@irstea.fr, jean-pierre.hamard@irstea.fr, sandrine.perret@irstea.fr,

12 thomas.perot@irstea.fr, nathalie.korboulewsky@irstea.fr

13

14 Manuscript:

10294 words

15

Abstract:

308 words

16

Number of tables:

4

17 Number of figures:

4

18

Number of references: 86

19

20

*Corresponding author: Irstea, UR EFNO, Domaine des Barres, F-45290 Nogent-sur-Vernisson,

France. Tel: 02.38.95.04.53. E-mail: anders.marell@irstea.fr. ORCID ID: 0000-0002-3328-4834

22 


\section{Abstract (max 400 words)}

Coppice forestry is a conventional silvicultural practice that takes advantage of a tree's capacity to respond to disturbances by sprouting. Sprouting capacity is determined by many intrinsic and extrinsic factors such as parent tree age/size, understory light availability and deer browsing, which, under closed canopy conditions are important limiting factors for stump survival or sprout growth. However, the combined effect of potentially confounding abiotic and biotic factors on stump survival and sprout growth remains elusive, even more so under closed canopy conditions. This study aims to quantify the effect of deer browsing on stump mortality and sprout growth under closed-canopy conditions and to compare this effect with other known determinants. Here we show that stump survival and sprout growth in sessile oak (Quercus petraea Matt.) depend on deer browsing, understory light availability and the diameter of the parent tree. By studying paired fenced-unfenced plots, we confirmed that deer browsing decreased stump survival and inhibited sprout growth. Furthermore, by taking advantage of a gradient in understory light availability in monospecific and mixed stands of sessile oak and Scots pine (Pinus sy/vestris L.), we showed a clear positive linear relationship between sprout growth and light availability. This relationship explained the observed differences among stand composition types. Finally, we found that increased understory light availability did not compensate for losses due to deer browsing. In the absence of deer browsing, our results demonstrate that sessile oak stumps regenerate well under closed-canopy conditions and maintain a moderate sprouting capacity at least until the age of 70-80 years old. Partial thinning could therefore be a potential tool to renew light-demanding tree species such as sessile oak in mixed high-forest stands. Nevertheless, we do not recommend coppicing sessile oak under closed canopies unless the oak stumps are protected from deer browsing and understory light availability is optimized as much as possible despite closed-canopy-management objectives. sylvestris 


\section{Introduction}

Deer populations have increased in numerous regions in the Northern Hemisphere (Apollonio et al., 2010; Kaji et al., 2010; Hewitt, 2011), where they have become locally overabundant. Several studies report damage to forest dynamics and biodiversity. For example, high browsing pressure has led to the biotic impoverishment and homogenization of forest understory plant communities (Rooney, 2009; Martin et al., 2010; Boulanger et al., 2018), and forest managers are finding it harder to regenerate the forest (Gill, 1992; Putman and Moore, 1998; Danell et al., 2003; Tremblay et al., 2007).

Silvicultural systems where trees regenerate vegetatively by producing stump sprouts and where the rotation is comparatively short are known as coppice forestry (Sjölund and Jump, 2013), and were once quite common in many parts of Western and Central Europe in lowland temperate broadleaf forests (Hédl et al., 2010). In some parts of Europe, coppice forestry has recently been revived in response to demands for nature conservation and renewable energy (Rydberg, 2000; Sjölund and Jump, 2013). Classical forms of coppicing are based on clear felling at regular intervals, varying from 7 to 40 years (Müllerová et al., 2016). Coppicing under closed canopy cover has also been traditionally used in mountain regions as a protection against soil erosion (Nocentini, 2009).

Recently, other forms of coppicing have been developed to take advantage of sprouting after thinning or partial cutting, this allows trees to regenerate under circumstances where the objectives are to maintain a closed canopy for conservation purposes and to preserve mixed tree species assemblages with minimal intervention (Götmark, 2013; Sjölund and Jump, 2013; Leonardsson and Götmark, 2015). In this context, coppicing is seen as a way to renew and preserve light-demanding tree species, such as oak, in association with more shade-tolerant tree species while maintaining a continuous cover of mixed forests. Oaks are of particular interest as they are known to have strong sprouting capacity and to maintain this ability well into old age (Del Tredici, 2001). The regeneration 
of oaks in temperate forests is subject to much controversy among forest researchers and practitioners (Götmark, 2007; Dey et al., 2012; Bobiec et al., 2018). Several factors have been proposed to explain the regeneration failure of oaks such as low light levels associated with the competition with shade-tolerant undergrowth (Kelly, 2002; Oliver et al., 2005), browsing by large herbivores (Buckley et al., 1998; Kuiters and Slim, 2002; Götmark et al., 2005) and large-scale disturbances (Bobiec et al., 2011; Dey et al., 2017).

Many tree species respond to disturbances by sprouting to develop secondary replacement trunks (sensu Del Tredici, 2001), thus rapidly regaining lost biomass and occupying space immediately after the disturbance (Bond and Midgley, 2001). The ability to sprout is fairly common among adult trees in all forest biomes (Vesk and Westoby, 2004) and plays an important role in driving forest dynamics (Van Bloem et al., 2007; Dietze and Clark, 2008; Edenius et al., 2011; Marzano et al., 2012). The capacity of tree stumps to survive and sprout after cutting is influenced by multiple intrinsic and extrinsic factors including the age and size of the parent tree (Del Tredici, 2001; Weigel and Peng, 2002; Matula et al., 2012; Splichalova et al., 2012), harvesting parameters such as cutting height and season (Harrington, 1984; Xue et al., 2013), the density of living residual trees and neighboring stumps (Matula et al., 2012; Svatek and Matula, 2015), thinning intensity and understory light availability (Ducrey and Boisserie, 1992; O'Hara and Berrill, 2010) and damage by deer browsing or pathogens (Kay, 1993; Cooke and Lakhani, 1996; Pyttel et al., 2013; Forrester et al., 2014; Marcais and Desprez-Loustau, 2014). Most of these factors can be controlled by the forest manager in order to optimize sprouting response after thinning or partial cutting, but the outcomes are uncertain as results on sprouting responses are contradictory.

This is particularly true for the oak genus (Quercus sp.), where results diverge among studies. On the one-hand, several studies of oaks have revealed negative relationships between parent tree diameter and stump survival and sprout growth (Khan and Tripathi, 1986; Weigel and Peng, 2002; 

sprout growth (H4).

Matula et al., 2012; Splichalova et al., 2012). On the other hand, other studies have found the opposite relationship (Xue et al., 2013) or no relationship at all (Leonardsson and Götmark, 2015). Likewise, the effect of thinning intensity remains elusive. Thinning intensity affected stump survival and sprout growth for Quercus nigra L. (Gardiner and Helmig, 1997), whereas a study on Quercus pagoda Raf. found no or very little effect (Lockhart and Chambers, 2007). This indicates that sprouting responses are either species-specific or interact with other factors not controlled for in the studies, such as deer browsing, pathogens, competing understory vegetation or forest stand history.

The present study aimed to simultaneously take into account the presence of deer browsing, light availability and neighboring species (stand composition) to study sprout survival and growth, and to assess their magnitude. From a management point of view, the main goal of the study was to evaluate whether partial thinning and the subsequent regrowth from cut stumps could be a potential method of forest renewal for a light-demanding tree species, in this case sessile oak (Quercus petraea Matt.), in high forest stands subjected to light to moderate deer browsing pressure. The objectives of the study were two-fold:

1) First, we compared sessile oak stump mortality and sprout growth in the presence and absence of deer in mono-specific and mixed stands of sessile oak and Scots pine (Pinus sylvestris L.). We hypothesized a negative impact of deer browsing on stump survival and sprout growth ( $\mathrm{H} 1$ ), and no effect of stand composition on these parameters ( $\mathrm{H} 2)$.

2) Second, we compared the explanatory power of deer browsing in relation to other intrinsic and extrinsic environmental factors potentially affecting stump mortality and sprout growth. We hypothesized that a large parent-tree diameter would increase stump mortality (H3), while increased light, small parent-tree diameters and low plant cover for neighboring vegetation would increase 


\section{Materials and Methods}

\section{$127 \quad 2.1$ Study site and sampling design}

128 The study took place in the center of France, in the Orleans National Forest (France, $47^{\circ} 49^{\prime} \mathrm{N}, 2^{\circ} 29^{\prime}$

129 E) where elevation ranges from $107 \mathrm{~m}$ to $174 \mathrm{~m}$ above sea level. Throughout the forest, the soil is 130 relatively poor and acidic with a sandy clay-loam texture, and is classified as a planosol (IUSS Working

131 Group WRB, 2015). Superimposed layers of clay and sand lead to a temporary perched water table in

132 winter, but the low soil water storage capacity reduces available water for plants in summer. The

133 area has a temperate continental climate with an oceanic influence: mean annual temperature is

$13410.8^{\circ} \mathrm{C}$ and mean annual rainfall is $729 \mathrm{~mm}$ based on $1981-2010$ data from the SAFRAN and the ISBA

135 analytical platforms provided by Météo-France (Durand et al., 1993).

Roe deer (Capreolus capreolus L.) and red deer (Cervus elaphus L.) are the main large herbivores, while large predators are absent from the study area. Wild boar (Sus scrofa L.) is also present, but is not known to cause any damage to oak sprouts, nor did we observe any damage that could be attributed to wild boar browsing during the study period. During the 2013/2014 hunting season, hunters killed on average 1.5 roe and 2.0 red deer individuals per square kilometer, indicating that the population densities of roe and red deer are low to moderate (Supplementary Figure 1). The study sites were equipped with camera traps (Moultrie 80XT) that were used to estimate local site use (hereafter 'local density') (Supplementary Figure 1). The estimated local density integrates habitat use and is not be confused with estimated absolute population density, as the camera traps were set up in particular forest habitats and not randomly throughout the home range of the deer population. We used a random encounter model (REM) to estimate local densities (Rowcliffe et al., 2008; Lucas et al., 2015). The average local density at the study plots was estimated as $0.041 \pm 0.013$ (mean $\pm S E ; n=6)$ and $0.11 \pm 0.032(n=6)$ individuals per square kilometer for red and roe deer, respectively. The large discrepancy between these estimates of local densities and the hunting 
151

152

153

154

155

156

157

158

159

160

161

162

163

164

165

166

167

168

169

170

171

172

statistics is mainly due to habitat selection. Our study plots were situated in mature forest stands

with relatively sparse understory vegetation. These habitats are often avoided by deer, who prefer young dense forest stands, forest edges or open habitats (Latham et al., 1996).

Six sites with paired fenced-unfenced 0.5-ha plots were set up in stands of sessile oak and Scots pine in the framework of the OPTMix experiment (Korboulewsky et al., 2015). Fences were erected in the winter of $2013 / 2014$ to exclude large wild ungulates; the fences are approximately $2.0 \mathrm{~m}$ tall with a mesh size of about $15 \mathrm{~cm}$. Our selected stands were even-aged stands between 70 and 80 years old with a dominant height of between 18 and $21 \mathrm{~m}$ for oaks and between 19 and $24 \mathrm{~m}$ for pines. The 12 plots, including the buffer zone ( $20 \mathrm{~m}$ wide), are all being managed under the same silvicultural treatments and they have similar forest stand characteristics (Table 1). The stands are relatively low density as a result of a dynamic management strategy which allows for understory regrowth from coppice stumps, similar to a coppice-with-standards (CWS) silvicultural system. The CWS system is composed of a two-story forest structure with a coppice understory and scattered taller singlestemmed trees as an overstory (Sjölund and Jump, 2013).

Table 1. Stand characteristics in 2015 of the paired fenced-unfenced study plots in even-aged monospecific stands of sessile oak (Quercus petraea Matt.) and Scots pine (Pinus sy/vestris L.), and in evenaged mixed stands of sessile oak and Scots pine at the six study sites $(012,0214,057,0216,083$, O200). $\mathrm{N}=$ number of stems per hectare; $\mathrm{G}=$ basal area per hectare at $1.3 \mathrm{~m}$ height; $\mathrm{DBH}=$ diameter at $1.3 \mathrm{~m}$ height; $\mathrm{PACL}_{\mathrm{OBS}}=$ percentage of observed above-canopy light at five random spots and at 2 $m$ in height

\begin{tabular}{|c|c|c|c|c|c|c|}
\hline & \multicolumn{2}{|c|}{ Oak } & \multicolumn{2}{|c|}{ Mixed } & \multicolumn{2}{|c|}{ Pine } \\
\hline & 012 & 0214 & 057 & 0216 & 083 & 0200 \\
\hline \multicolumn{7}{|l|}{ Unfenced } \\
\hline $\mathrm{N}_{\text {oak }}$ (stems/ha) & 392 & 370 & 252 & 215 & - & - \\
\hline $\mathrm{G}_{\text {oak }}\left(\mathrm{m}^{2} / \mathrm{ha}\right)$ & 14.5 & 14.7 & 9.9 & 8.1 & - & - \\
\hline $\mathrm{DBH}_{\text {oak }}(\mathrm{cm})$ & $20.9(6.0)$ & $21.7(5.8)$ & $21.1(7.4)$ & $21.1(5.9)$ & - & - \\
\hline
\end{tabular}




$\begin{array}{lcccccc}\mathrm{N}_{\text {pine }}(\text { ind } / \text { ha }) & - & - & 86 & 112 & 290 & 200 \\ \mathrm{G}_{\text {pine }}\left(\mathrm{m}^{2} / \mathrm{ha}\right) & - & - & 10.6 & 9.3 & 25.4 & 19.5 \\ \mathrm{DBH}_{\text {pine }}(\mathrm{cm}) & - & - & 39.2(6.1) & 31.8(6.1) & 32.9(5.5) & 34.9(4.9) \\ \mathrm{PACL}_{\mathrm{OBS}}(\%) & 21.4(2.6) & 19.8(2.2) & 29.8(3.6) & 30.2(4.0) & 36.3(1.9) & 34.3(7.8)\end{array}$

Fenced

\begin{tabular}{lcccccc}
$\mathrm{N}_{\text {oak }}$ (ind/ha) & 354 & 294 & 194 & 170 & - & - \\
$\mathrm{G}_{\text {oak }}\left(\mathrm{m}^{2} / \mathrm{ha}\right)$ & 15.3 & 14.0 & 8.5 & 7.1 & - & - \\
$\mathrm{DBH}_{\text {oak }}(\mathrm{cm})$ & $22.6(6.3)$ & $24.0(5.6)$ & $22.5(7.3)$ & $21.8(7.8)$ & - & 202 \\
$\mathrm{~N}_{\text {pine }}(\mathrm{ind} / \mathrm{ha})$ & - & - & 94 & 116 & 239 & 24.6 \\
$\mathrm{G}_{\text {pine }}\left(\mathrm{m}^{2} / \mathrm{ha}\right)$ & - & - & 11.7 & 9.8 & 19.4 \\
$\mathrm{DBH}_{\text {pine }}(\mathrm{cm})$ & - & - & $39.3(6.6)$ & $32.0(7.5)$ & $35.8(5.3)$ & $34.7(4.4)$ \\
$\mathrm{PACL}_{\text {OBS }}(\%)$ & $20.7(3.7)$ & $17.2(4.2)$ & $28.8(4.8)$ & $28.4(3.9)$ & $35.1(4.2)$ & $33.4(1.7)$ \\
\hline
\end{tabular}

\subsection{Stump mortality and sprout growth}

175

The study plots were thinned during the 2012-2013 and 2013-2014 winter seasons (Table 2) in order to reach targeted stand tree composition (monospecific and mixed stands) and densities (low density). Cut stems were monitored in March 2015 and 2016, just before the start of the plant growing season. A stump was considered dead if it had no living buds or shoots at the time of the inventories. For all living stumps, the vertical height of the tallest shoot was measured as well as the length of the five most vigorous shoots. Vertical shoot height was defined as the vertical distance between the ground and the tip of the shoot and shoot length was defined as the distance following the curvature of the stem from the base to the tip of the shoot. The five most vigorous shoots were tagged in 2015 and re-measured in 2016. Sprout growth in the 2015 growing season was estimated by calculating the difference in height/length of the shoots between the two measuring campaigns; this figure was used in subsequent analyses on sprout growth capacity. Signs of deer browsing (twigs showing a ragged tear or splintered cut on one side) and fraying (bark rubbed off by the antlers) or other types of damages by rodents (twigs showing sharp and inclined scissor-like cuts, bark gnaws and peeling), gall formations (abnormal outgrowths), plant tissue losses due to insect herbivory (ragged leaf edges, leaves perforated, skeletonization, leaf mining patterns), fungal attacks 
(discoloration, wilting, fruiting bodies), climatic events (dead tissue, wilting) and damage of other origins were recorded at the stump level.

In all, 301 oak stumps were monitored for two years (2015 and 2016) of which 148 (49.2\%) were still alive at the end of the study. All stumps in the pure oak stands originated from single-stemmed parent trees, while $15-20 \%$ of the stumps in the pure pine and mixed stands originated from multistemmed parent trees. Multi-stemmed parent trees likely originated from former coppices, contrary had been planted as seedlings. Furthermore, all the parent trees in the pure pine stands were subordinate oak trees before thinning, whereas in the mixed pine / oak and pure oak stands, respectively $92-96 \%$ and $75-77 \%$ of the parent trees were subordinate. Six hundred and sixty-six shoots were tagged in 2015, of which 563 shoots were re-measured in 2016 to calculate annual growth in length. The other 103 shoots had died. The overall average $\mathrm{DBH}_{\text {parent }}$ of cut trees was 15.9 $\mathrm{cm}(\mathrm{SD}=4.7 \mathrm{~cm}$, range $7-25.2 \mathrm{~cm}, \mathrm{n}=301)$.

Table 2. Date of thinning events and the number of oak stumps monitored at the six study sites in the paired fenced-unfenced 0.5-ha plots

\begin{tabular}{|c|c|c|c|c|c|c|}
\hline & \multicolumn{2}{|c|}{ Oak } & \multicolumn{2}{|c|}{ Mixed } & \multicolumn{2}{|c|}{ Pine } \\
\hline & 012 & 0214 & 057 & 0216 & 083 & O200 \\
\hline \multicolumn{7}{|l|}{ Thinning } \\
\hline Date & Dec 2012 & Jan 2013 & Dec 2012 & Nov 2013 & Nov 2013 & Feb 2014 \\
\hline \multicolumn{7}{|c|}{ Number of oak stumps } \\
\hline Unfenced & 29 & 30 & 27 & 30 & 16 & 21 \\
\hline Fenced & 30 & 30 & 21 & 30 & 16 & 21 \\
\hline
\end{tabular}

\subsection{Covariates}

209 For each of the 12 plots, all trees with a diameter above $7.5 \mathrm{~cm} \mathrm{DBH}$ were inventoried and mapped before and after thinning. We used diameter at breast height of the parent tree $\left(\mathrm{DBH}_{\text {parent }}\right)$ as a potential explanatory variable and as a proxy for tree size. 
213 Understory light availability at oak stump locations was estimated by a model based on the Beer-

214 Lambert law, which predicts from data on basal area the percent of above-canopy light (PACL) that

215 reaches the understory vegetation (Sonohat et al., 2004; Balandier et al., 2006). The model had been

216 calibrated for mono-specific and mixed stands of sessile oak and Scots pine and its predictive ability evaluated for the plots concerned (see Perot et al., 2017). As proposed by Perot et al. (2017), a single model was applied to both mono-specific and mixed stands as follows:

$$
P A C L_{i}=e^{\left(-b_{\text {oak }} G_{\text {oak }}-b_{\text {pine }} G_{\text {pine }}\right)}+\varepsilon_{i}
$$

where $P A C L_{i}$ is the percent of above-canopy light at point $i, G$ is the local basal area per hectare at

point $i, b$ is the coefficient of extinction and $\varepsilon_{i}$ is the residual part of the model. Parameters and variables associated to sessile oak are annotated with the oak index and those associated with Scots pine are annotated with the pine index. PACL is defined as the ratio between below-canopy and above-canopy photosynthetically active radiation (PAR), which is the equivalent of the solar radiation transmittance of the tree canopy. Model predictions of PACL are hereafter referred to as PACLEST.

Competition with the surrounding vegetation was determined within a radius of two meters centered on the stumps by visually estimating the vertical projection of plant cover of the most common and most dominant understory plant species (Molinia caerulea L., Calluna vulgaris L., Pteridium aquilinum L., Rubus fruticosus agg. L.). Seven classes were used: absence, cover $<1 \% ; 1 \%<$ cover < 5\%; $5 \%<$ cover < 20\%; $20 \%<$ cover < 50\%; $50 \%<$ cover $<75 \%$; and $75 \%<$ cover $<100 \%$. We pooled the cover data before all subsequent analyses and assumed the independence of the spatial distribution of plant individuals. We applied the method developed by Fischer (2015) to estimate overall plant cover for the understory vegetation layer. The pooled plant cover was bounded between $0-100 \%$. 


\subsection{Statistical analyses}

238 Generalized mixed effects models (GLMM) were used to test the effect of deer browsing and stand

239 composition on oak stump mortality and sprout growth capacity. A random intercept model was

240 fitted as reference model to test for differences related to the experimental design, where stand composition and herbivore exclusion and their interaction were fixed terms. For analyses at the stump level, the random terms were composed of site and study plot nested within site in order to take into account the nested sampling design of paired fenced-unfenced plots. For analyses at the shoot level, stump was added as an additional random effect nested within plot. Then, in order to see whether $\mathrm{DBH}_{\text {parent, }}$ PACL $\mathrm{EST}$ and plant cover of competing vegetation-potential covariatesimproved model fitting or could replace one of the fixed terms in the reference model, they were added to the model which was then compared to the reference model. Finally, a minimal adequate model was selected corresponding to the most parsimonious model. Model selection was based on the Akaike information criterion adjusted for small sample size (AICC) (Burnham and Anderson, 1998). When the difference between the minimum AICc value and the AICc values of the other possible models was less than 2, we judged the models to be of equivalent explanatory power and retained the most parsimonious one.

We used the maximum likelihood (ML) estimation method to compare and fit the models because we were comparing models that had different fixed effects (Pinheiro and Bates, 2000). The final selected models were fitted with the restricted maximum likelihood (REML) method in order to better estimate the variance components (Pinheiro and Bates, 2000). Model efficiency (EF), which can be used as a proxy for the proportion of variation explained in non-linear models (Mayer and Butler, 1993), was calculated as follows:

$$
E F=1-\frac{\sum\left(y_{i-} \widehat{y}_{l}\right)^{2}}{\sum\left(y_{i-} \bar{y}\right)^{2}}
$$


where $y_{i}$ is the observed value, $\widehat{y}_{l}$ is the fitted value and $\bar{y}$ is the mean of the observed values. $E F$ was computed both with and without random effects, which allowed us to evaluate the proportions explained by the fixed and the random part of the model.

For stump mortality, which is a binary variable (dead or alive), we used a binomial error distribution. For shoot growth, which is a continuous variable, we used a normal error distribution. Statistical analyses were performed with the R software, version 3.1.0 (R Development Core Team, 2011). Mixed effects models were run with the glmer function of the Ime4 package for data with a binomial error distribution (Bates et al., 2014) and with the Ime function of the nIme package for data with a normal error distribution (Pinheiro et al., 2011).

\section{Results}

\subsection{Stump survival}

Oak stump survival after 2-3 growing seasons in late winter 2016 was on average 1.6 times higher in fenced than in unfenced plots (Figure 1). Adding $\mathrm{DBH}_{\text {parent }}$ enhanced model predictions (Table 3) and showed a negative linear correlation between survival rate and $\mathrm{DBH}_{\text {parent }}$ (Figure 2). Although stand composition and its interaction with herbivory were not retained in our most parsimonious model, we observed a lower survival rate $\left(P_{\text {oak }}=0.03\right.$ and $\left.P_{\text {pine }}=0.02\right)$ of oak stumps inside fenced plots in mixed oak-pine stands (see Supplementary Figure 3). 


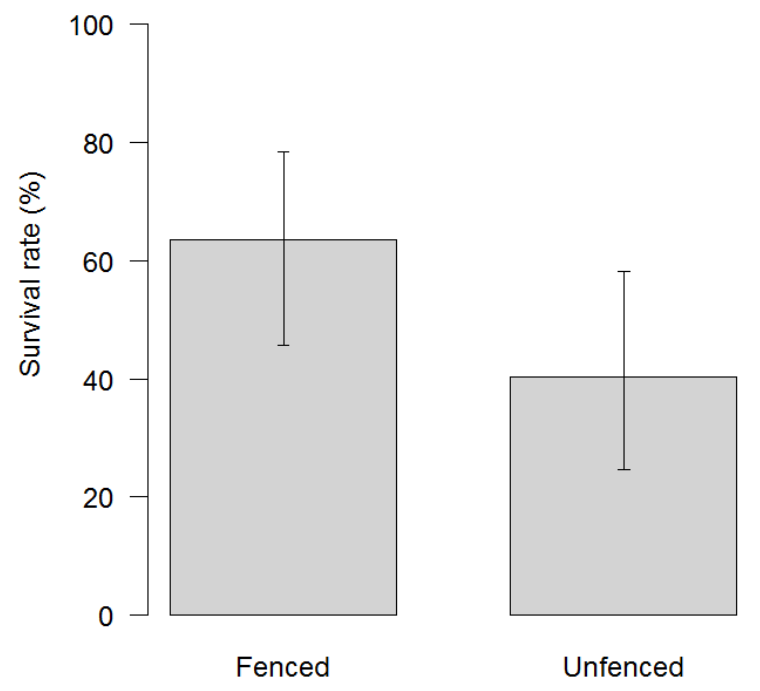

282 Figure 1. Survival rate of oak stumps in late winter 2016 in fenced and unfenced plots. Values

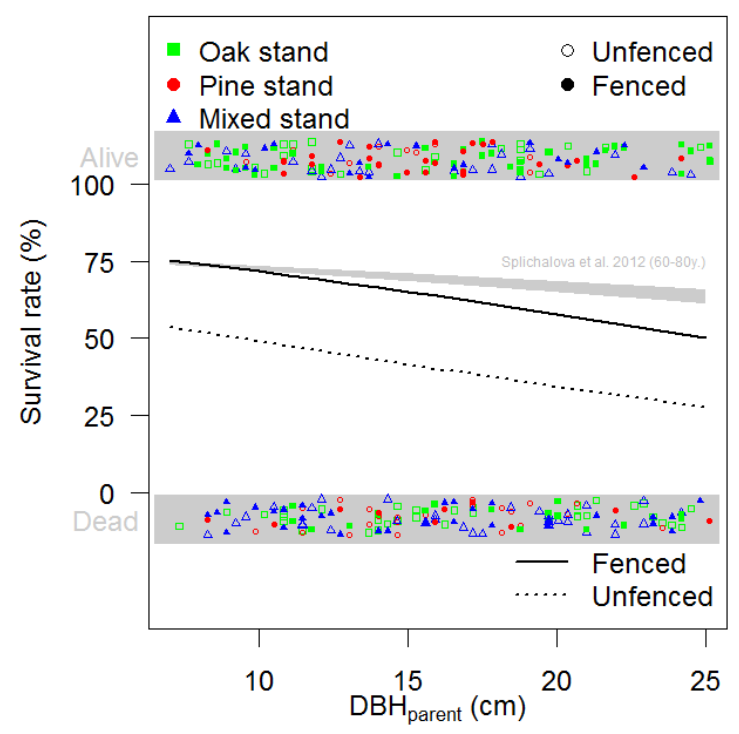

287 Figure 2. Observed survival (alive or dead) in 2016 of 301 oak stumps in relation to the diameter at breast height of the parent tree, $\mathrm{DBH}_{\text {parent, }}$ as well as the predicted survival rates for stumps in fenced (solid line) and unfenced (dotted line) plots taken from the most parsimonious $\mathrm{GLMM}_{\text {binom. }}$. For comparison, the results obtained by Splichalova et al. (2012) for equivalent tree ages and diameters are shown as a shaded gray interval. 
293 Table 3. Summary of the statistics for the models predicting the survival rate (SURV) of sessile oak

294 stumps in mono-specific and mixed sessile oak/Scots pine stands

\begin{tabular}{|c|c|c|c|c|c|c|c|}
\hline Model $^{\S}$ & $\mathrm{N}$ & $\mathrm{df}$ & $\sigma_{\text {site }}$ & $\sigma_{\text {plot }}$ & $\mathrm{AICc}$ & $E F_{\text {full }}$ & $\mathrm{EF}_{\mathrm{fix}}$ \\
\hline \multicolumn{8}{|l|}{ Null model } \\
\hline SURV = INTERCEPT & 301 & 3 & $<0.001$ & 0.80 & 399.4 & 0.16 & - \\
\hline \multicolumn{8}{|l|}{ Reference model (experimental design) } \\
\hline SURV $=\mathrm{C}+\mathrm{H}+\mathrm{C} \times \mathrm{H}$ & 301 & 8 & 0.32 & $<0.001$ & 396.5 & 0.15 & 0.10 \\
\hline SURV $=\mathrm{H}$ & 301 & 4 & 0.37 & 0.21 & 397.8 & 0.16 & 0.037 \\
\hline \multicolumn{8}{|c|}{ Diameter at breast height of the parent tree $\left(D B H_{\text {parent }}\right)$ as covariate } \\
\hline SURV $=\mathrm{C}+\mathrm{H}+\mathrm{C} \times \mathrm{H}+\mathrm{DBH}_{\text {parent }}$ & 301 & 9 & 0.30 & $<0.001$ & 393.1 & 0.17 & 0.12 \\
\hline SURV $=\mathrm{C}+\mathrm{H}+\mathrm{C} \times \mathrm{H}+\mathrm{DBH}_{\text {parent }}+\mathrm{H} \times \mathrm{DBH}_{\text {parent }}$ & 301 & 10 & 0.31 & $<0.001$ & 394.2 & 0.17 & 0.12 \\
\hline SURV $=\mathrm{H}+\mathrm{DBH}_{\text {parent }}$ & 301 & 5 & 0.19 & 0.42 & 394.6 & 0.18 & 0.051 \\
\hline
\end{tabular}

295

296

297

298

299

300

301

302

303

304

305

306

307

308

$\overline{{ }^{\mathrm{A}} \mathrm{A} \text { first model was fitted that tested for differences related to the experimental design (reference model), where stand }}$ composition $(\mathrm{C})$, herbivore exclusion $(\mathrm{H})$ and their interaction were fitted as fixed terms. The random term was composed of site and study plot nested within site in order to take into account the nested sampling design (paired fenced-unfenced plots). $\mathrm{DBH}_{\text {parent }}$ was added as a covariate (including interaction terms) in order to see whether this variable improved model fitting or could replace one of the fixed terms in the first model. Model selection was based on the Akaike information criterion adjusted for small sample size (AICC). Only the best models, with a difference in AICC of less than 2 , are displayed. The most parsimonious models are shown in bold.

\subsection{Sprout growth}

The annual maximum height growth on oak stumps was greater in fenced than in unfenced plots

(Figure 3a), the latter showing on average an annual height growth equal to zero in all stand compositions (Figure 3a). In fenced plots, sprout growth differed among stand compositions (Table 4). Growth tended to be the strongest for oak stumps in mono-specific pine stands (mean $\pm \mathrm{Cl}$; $62.5 \pm 22.3 \mathrm{~cm})$, intermediate in mixed oak-pine stands $(31.8 \pm 16.9 \mathrm{~cm})$ and the weakest in mono- 

stump showed a similar pattern (Figure $3 b$ ).

(a)

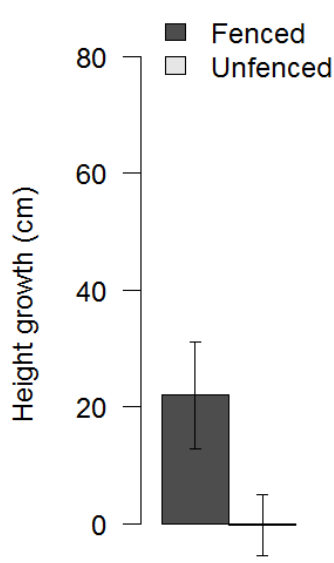

Oak



Mixed

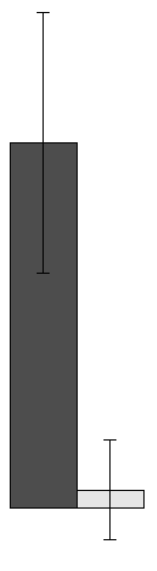

Pine (b)

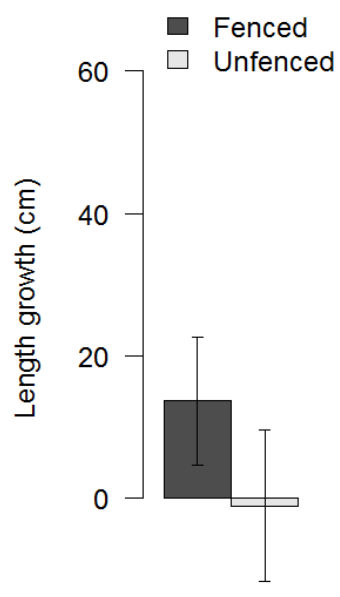

Oak



Mixed

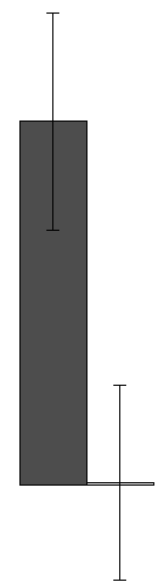

Pine
312

Figure 3. Predicted annual growth in (a) sprout height and (b) length of the five most vigorous shoots from oak stumps during the 2015 growing season in fenced and unfenced plots in mono-specific and mixed sessile oak/Scots pine stands. Error bars represent the $95 \%$ confidence interval around the model predictions.

Further, we found that annual height growth of shoots from oak stumps was equally well explained by a model where composition was replaced by $\mathrm{PACL}_{\mathrm{EST}}$ (percent of above-canopy light). Although the model with $\mathrm{PACL}_{\mathrm{EST}}$ had a slightly higher $\mathrm{AICC}(\Delta=0.61)$ than the model with composition and explained less of the variability (49\% versus $51 \%$ ) (Table 4 ), we gained in model simplicity. That is, the model had fewer parameters because a continuous variable replaced a categorical variable with three levels. Indeed, PACLEST differed at stump locations among stand compositions (Figure 4). $\mathrm{PACL}_{\text {EST }}$ was the greatest for stumps in pine stands (mean $=43 \%, \min =35 \%, \max =51 \%, \mathrm{SD}=4.1 \%, \mathrm{n}$ $=35$ ), intermediate in mixed stands ( $\operatorname{mean}=33 \%, \min =24 \%, \max =45 \%, S D=4.4 \%, n=57$ ) and the least in oak stands $($ mean $=24 \%, \min =19 \%, \max =36 \%, S D=3.3 \%, n=71)$. In fenced plots, the 
Table 4. Summary of statistics for the models predicting annual height growth (HEIGHT) of sprouts on

model predicted a $14.4 \mathrm{~cm}$ increase in annual height growth for every $10 \%$ increase in $\mathrm{PACL}_{\mathrm{EST}}$, while in unfenced plots the growth was not significantly different from zero irrespective of $\mathrm{PACL}_{\text {EST }}$ (Figure 4).

Adding $\mathrm{DBH}_{\text {parent }}$ or total plant cover as covariates did not improve model fitting for either annual sprout growth in height or annual growth in length of the five most vigorous shoots from oak stumps (Table 4 and Supplementary Table 1). (a)

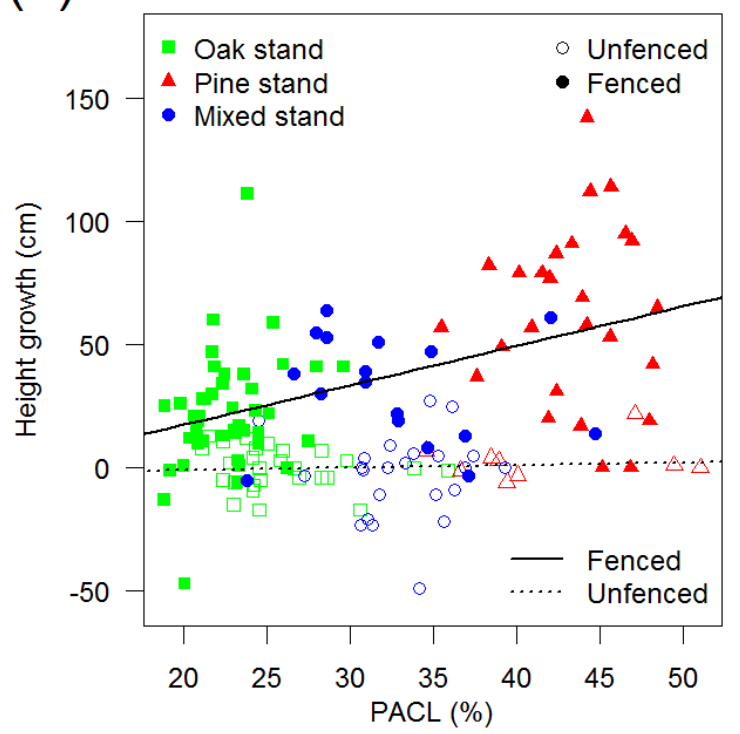

(b)

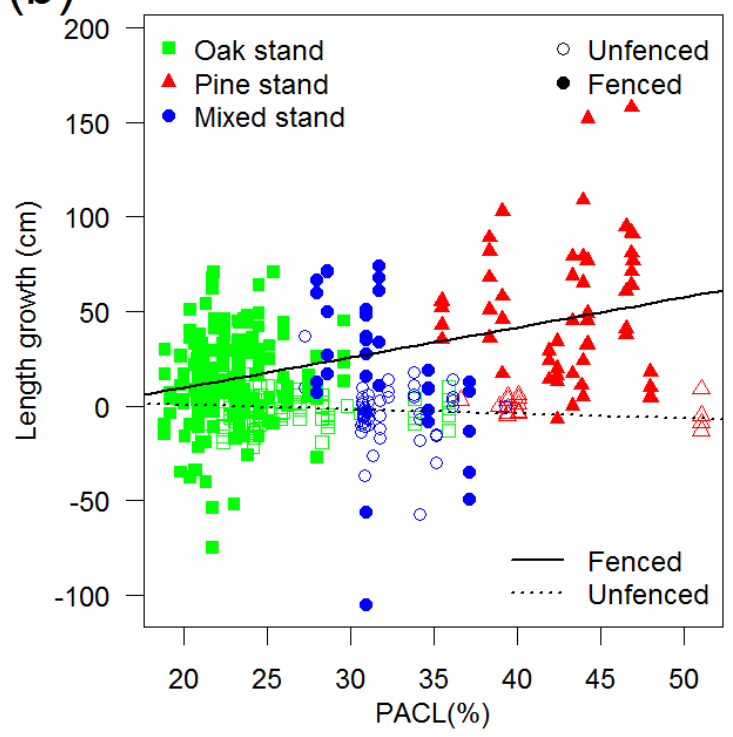

Figure 4. Observed annual growth in (a) sprout height and (b) length of the five most vigorous shoots from oak stumps during the 2015 growing season in fenced and unfenced plots in mono-specific and mixed sessile oak/Scots pine stands in relation to the percent of above-canopy light (PACLEST).


displayed.

sessile oak stumps in mono-specific and mixed sessile oak/Scots pine stands

\begin{tabular}{lllllllll}
\hline Model $^{\S}$ & $N$ & $d f$ & $\sigma_{\text {site }}$ & $\sigma_{\text {plot }}$ & $\sigma_{\text {resid. }}$ & AlCc & $E F_{\text {full }}$ & $E F_{\text {fix }}$
\end{tabular}




\section{Null model}

$\begin{array}{llllllll}\text { HEIGHT = INTERCEPT } & 301 & 4 & <0.001 & 554.5 & 507.2 & 1355.7 & 0.54\end{array}$

Reference model (experimental design)

HEIGHT $=\mathrm{C}+\mathrm{H}+\mathrm{C} \times \mathrm{H}$

$301 \quad 14<0.001$

$<0.001$

541.0

$1291.6 \quad 0.51$

0.51

Diameter at breast height of the parent tree ( $\left.D B H_{\text {parent }}\right)$ as covariate

$\begin{array}{lrrrrrrrr}\text { HEIGHT }=\mathrm{C}+\mathrm{H}+\mathrm{C} \times \mathbf{H}+\text { DBH }_{\text {parent }} & 301 & \mathbf{1 5} & <0.001 & <0.001 & \mathbf{5 4 0 . 4} & \mathbf{1 2 9 4 . 1} & \mathbf{0 . 5 1} & \mathbf{0 . 5 1} \\ \text { HEIGHT }=\mathrm{C}+\mathrm{H}+\mathrm{C} \times \mathrm{H}+\mathrm{DBH}_{\text {parent }}+\mathrm{H} \times \mathrm{DBH}_{\text {parent }} & 301 & 16 & <0.001 & <0.001 & 534.4 & 1295.5 & 0.51 & 0.51\end{array}$

Percentage of above-canopy light $\left(P A C L_{E S T}\right)$ as covariate

HEIGHT $=\mathbf{H}+$ PACLEST $+H \times$ PACLEST

HEIGHT $=\mathrm{C}+\mathrm{H}+\mathrm{PACL}_{\text {EST }}+\mathrm{H} \times \mathrm{PACL}_{\text {EST }}$

Total plant cover (COVER $R_{T O T}$ ) as covariate

\begin{tabular}{|c|c|c|c|c|c|c|c|c|}
\hline HEIGHT $=\mathrm{C}+\mathrm{H}+\mathrm{C} \times \mathrm{H}+$ COVERTOT & 301 & 15 & $<0.001$ & $<0.001$ & 543.0 & 1294.0 & 0.51 & 0.51 \\
\hline HEIGHT $=\mathrm{C}+\mathrm{H}+\mathrm{C} \times \mathrm{H}+$ COVERToT $+\mathrm{H} \times$ COVERToT & 301 & 16 & $<0.001$ & $<0.001$ & 533.6 & 1295.8 & 0.51 & 0.51 \\
\hline HEIGHT $=\mathrm{C}+\mathrm{H}+\mathrm{C} \times \mathrm{H}+$ COVERTOT $+\mathrm{C} \times$ COVERTOT & 301 & 17 & $<0.001$ & $<0.001$ & 545.7 & 1295.8 & 0.51 & 0.51 \\
\hline
\end{tabular}

$\begin{array}{llllllll}301 & 12 & <0.001 & <0.001 & 503.1 & 1292.2 & \mathbf{0 . 4 9} & \mathbf{0 . 4 9} \\ 301 & 14 & <0.001 & <0.001 & 506.6 & 1293.4 & 0.50 & 0.50\end{array}$

${ }_{\S} \mathrm{A}$ first model was fitted to test for differences related to the experimental design (reference model), where stand composition $(\mathrm{C})$, herbivore exclusion $(\mathrm{H})$ and their interaction were fixed terms. The random term was composed of site and study plot nested within site in order to take into account the nested sampling design (paired fenced-unfenced plots).

Covariates were added to the model to see whether they improved model fitting or could replace one of the fixed terms in the first model. Model selection was based on the Akaike information criterion adjusted for small sample size (AICC). Only the best models with a difference in AICC of less than 2 are displayed. The most parsimonious models are shown in bold.

\subsection{Shoot damage}

All the stumps (100\%) in the unfenced plots were browsed by deer and showed few signs of other types of damage (13.0\% in 2015 and 4.1\% in 2016). Although no browsing by deer was observed inside fenced plots, damage did occur: in 2015 and 2016, respectively, only $16.3 \%$ and $6.9 \%$ of stumps and $49.1 \%$ and $66.2 \%$ of tagged shoots were undamaged in the fenced plots. Some damage in the fenced plots was unidentified but we were able to determine most causes: powdery mildew attacks (36.9\% 2015 and $21.6 \%_{2016}$, though frost damage could not be excluded as plausible alternative 
cause), browsing by hares and small rodents $\left(<1 \%_{2015}\right.$ and $\left.4.0 \%_{2016}\right)$, and parasitic damage mostly due to gall formation and plant tissue losses through insect herbivory $(<1 \%)$. Competing vegetation hindered growth for less than $<1 \%$ of shoots in 2015 and $3.1 \%$ in 2016 . Oak shoots in pure pine stands had less damage in 2015 (corresponding to the 2014 growing season) than the shoots in monospecific oak and mixed stands (Supplementary Figure 2). Powdery mildew attacks (or possibly frost damage) were less common in pine stands during the entire study period and less common in mixed stands in 2016 (corresponding to the 2015 growing season) (Supplementary Figure 2b). An increase in damage caused by rodents and lagomorphs as well as hindered growth by vegetation competition was observed in monospecific pine and mixed stands in 2016 (Supplementary Figure 2c,d). Some parasitic attacks on oak shoots in monospecific oak stands were also observed in 2016, but not in monospecific pine and mixed stands. Finally, concerning repeated seasonal damage, in unfenced plots, the shoots tagged in 2015 that were found dead in 2016 had all but one been browsed at the time of measurement during previous growing season (65 shoots). In fenced plots, three quarters of the dead shoots had shown signs of damage by powdery mildew/frost (61\%) and to a lesser extent by rodent/lagomorph browsing (11\%) during the previous growing season; one quarter of the dead shoots had shown no signs of damage when measurements were taken during the previous growing season.

\section{Discussion}

We examined the effect of deer browsing on oak stump survival and sprout growth capacity. In accordance with $\mathrm{H} 1$, deer browsing negatively affected both the survival and growth of stump sprouts. However, contrary to $\mathrm{H} 2$, oak sprout growth differed among the three stand composition types (mono-specific and mixed oak/pine stands). In agreement with $\mathrm{H} 4$, we showed that these differences were partly due to differences in understory light availability among stand composition types. Contrary to $\mathrm{H} 4$, we found no effect on growth of total competing vegetation cover or diameter 
at breast height of the parent tree ( $\left.\mathrm{DBH}_{\text {parent }}\right)$. Although $\mathrm{DBH}_{\text {parent }}$ had no effect on sprout growth, it did have a relatively strong negative effect on stump survival, in agreement with $\mathrm{H} 3$.

\subsection{Effects of deer browsing}

Oak stumps experienced high browsing pressure: all the stumps in the unfenced plots were browsed despite low to moderate deer population densities. Taking into account data from the camera trap survey, local densities could even be considered very low. The high browsing pressure observed was probably due palatability; stump sprouts are highly-preferred browse for deer, more than shoots from seedlings and saplings that originate from seeds (Moore and Johnson, 1967). Consequently, and in agreement with previous studies (Cooke and Lakhani, 1996; Espelta et al., 2006; Cutini et al., 2011; Pyttel et al., 2013; Forrester et al., 2014; Royo et al., 2016), we showed that deer browsing reduced the height growth of oak stump shoots. Although stump sprouts are highly resilient to herbivory due to their carbohydrate reserves (Bond and Midgley, 2001; Nzunda et al., 2014), we showed that sprout growth can still be totally inhibited. The mean maximum sprout height only reached the lower limit of the browsing zone ('molar zone'; 0.2-1.8 m; Waller and Alverson, 1997; Frerker et al., 2013). In a short-term perspective, this is in line with the 'browsing lawn' concept (Cromsigt and Kuijper, 2011), in which intense browsing leads to increased resource availability (leaves and shoots within the browsing height) and a proportional increase of palatable resources (oak sprouts) in the patch. However, in a long-term perspective, it is likely that the positive effect of the immediate increase in palatable food resources due to browsing will quickly fade away as stump mortality caused by the same browsing increases (see below). Likewise, Cooke and Lakhani (1996) showed that ash sprouts ceased to grow in height in unfenced areas that experienced high browsing pressure by muntjac deer. However, forage preferences vary with tree species, and deer densities can differ greatly among sites. This means that browsing pressure on sprouts can vary widely among forest areas (Royo et al., 2016). In other studies, the effect of deer browsing was less important, or even negligible, for less palatable tree species than oak or in areas with apparently low deer population densities (Cutini 
et al., 2011; Royo et al., 2016). These findings corroborate the idea that deer population densities do not linearly translate into equivalent deer browsing impacts. Rather, they suggest that browsing impact is context-dependent and depends on many factors other than deer density alone.

In line with the results obtained by Pyttel et al. (2013), we observed that oak stump mortality was higher in unfenced plots. Probably the high browsing pressure on shoots and the repeated consumption of sprouts in the unfenced areas increased stump mortality, similarly to what has been shown for shrubs sprouting from below-ground organs (Moreno and Oechel, 1991). It is therefore likely that repeated deer browsing depletes the plant's stored reserves (Paula and Ojeda, 2011; Schutz et al., 2011) and subsequently causes the plant to die (Canadell and Lopez-Soria, 1998). Royo et al. (2016), on the other hand, found no relationship between deer browsing and tree stump sprouting probability. None of the tested covariates or the correlations among covariates was able to explain the difference in survival rate we found between mixed and mono-specific stands. Most likely, the higher mortality in fenced mixed stands was due to higher attack rates of powdery mildew (Supplementary Figure 2). Here it seems as if the oak stumps in pure pine stands benefited from the absence of adult oak trees in the canopy which could be a local contamination source; much fewer powdery mildew attacks were observed in pure pine stands. Powdery mildew infections are known to be particularly severe on oak coppicing, but also to be present in mature trees where it is an aggravating factor after insect defoliation (Marcais and Desprez-Loustau, 2014). It is also possible that the observed lower survival rates were due to unknown differences in forest stand history such as ancient forest fires or previous coppice treatments. However, we would then have expected a lower survival rate in both the fenced and unfenced plots in the mixed stands, which was not the case. Indeed, the survival rate in the unfenced mixed plots and the unfenced pure stands was similar to the low rate in fenced mixed plots. Unknown covariates such as belowground interactions, including competitive interactions, and fungal infections could also account for the observed differences. 


\subsection{Effects of understory light availability}

437 The quantity of light that reaches the forest floor is a strong determinant of growth, density and species composition of trees, shrubs and herbaceous plants under closed canopy conditions (Kobe et al., 1995; Decocq et al., 2004; Bartels and Chen, 2010). Not surprisingly, we found a positive linear relationship between understory light availability and sprout height growth for oak stumps protected from deer in the fenced plots. This is in agreement with other studies on oak stumps that have found shoot height growth to be higher in heavily thinned stands than in lightly thinned ones (Ducrey and Boisserie, 1992; Gardiner and Helmig, 1997). However, Lockhart and Chambers (2007) did not find any significant differences between lightly and heavily thinned stands. In our unfenced plots, we found that high understory light availability did not compensate for the impacts of deer browsing. Height growth was nil irrespective of light levels, even at the highest observed light availability. We believe that this was due to repeated browsing of shoots, which constantly kept them at the lower limit of the browsing zone.

\subsection{Effects of diameter at breast height of the parent tree}

Tree age and size is a strong determinant of forest dynamics; inequalities in tree size affect tree responses to disturbances (Merlin et al., 2015), competitive interactions among neighbors (Cordonnier and Kunstler, 2015) and productivity (Bourdier et al., 2016). We showed that stump mortality increased with increasing size of the parent tree ( $\left.\mathrm{DBH}_{\text {parent }}\right)$. These results are in line with 455 North American (Dey and Jensen, 2002; Weigel and Peng, 2002; Sands and Abrams, 2009) and other European (Matula et al., 2012; Splichalova et al., 2012) studies of oak species. The predicted decrease in stump survival between the smallest and the largest trees in our sample set $(25.1 \%)$ was equivalent to the observed drop in stump survival between fenced and unfenced plots (23.2\%). From 
sessile oak trees in the absence of deer browsing, while sprouting is unacceptably low for larger trees in the presence of deer browsing. Compared to other European tree species, the survival rate of sessile oak stumps seems to be intermediate, lying between strongly-sprouting tree species such as the small-leaved lime (Tilia cordata Mill.) and European hornbeam (Carpinus betulus L.), and weaklysprouting tree species such as silver and downy birch (Betula pendula L. and B. pubescens L.) and European beech (Fagus sylvatica L.) (Rydberg, 2000; Matula et al., 2012; Leonardsson and Götmark, 2015).

\section{Conclusion}

Our results show that deer browsing was the most important determinant of sprouting capacity with strong effects on both stump survival and sprout growth. Diameter at breast height of the parent tree ( $\mathrm{DBH}_{\text {parent, }}$ a proxy for tree size) was as important as deer browsing with regard to stump survival. For sprout growth, understory light availability was of lesser importance than deer browsing. We confirmed the results of other studies that deer browsing increases stump mortality and can even totally inhibit the height growth of coppice shoots under closed-canopy conditions, even at low deer population densities. We conclude that deer browsing is an important factor potentially responsible for explaining vegetative regeneration failures of oaks in temperate forests and forest managers should therefore carefully consider the presence of deer when coppicing is the desired management system. Furthermore, we do not recommend coppicing under closed canopy cover as a silvicultural practice unless stumps are protected from deer browsing. Even at relatively high light availabilities $(\mathrm{PACL}=50 \%$ ) corresponding to relatively large canopy openings, light was not sufficient to compensate for the losses due to deer browsing.

\section{We also showed that understory light availability is a determinant for sprout growth, but that it did} not seem to have any major effect on stump survival. On the other hand, $\mathrm{DBH}_{\text {parent }}$ did have a 
relatively strong negative effect on stump survival, though our results confirm that sessile oak maintains an acceptably sprouting capacity into older age in the absence of deer browsing. These results imply that partial thinning could be useful to renew sessile oak under closed canopy conditions and to preserve light-demanding tree species in association with more shade-tolerant tree species in mixed high-forest stands. However, one should interpret our results cautiously as our study only spans two to three growing seasons, and does not take into consideration the long-term survival of re-sprouts under closed canopy conditions.

Additionally, we showed that the effect of a covariate (in our case PACL) on a response variable (sprout growth) might depend on another explanatory variable (deer browsing). These kinds of interactions may explain why some previous studies have found contradictory results. More specifically, in our study, browsing pressure cancelled or neutralized the effect of understory light availability (PACLEST) and might explain some previous results related to the effect of thinning intensity. We therefore recommend that confounding factors be carefully taken into account and that deer browsing should systematically be controlled for in the experimental design of future studies on tree re-sprouting capacity.

\section{Acknowledgements}

This work was carried out at the OPTMix (Oak Pine Tree Mixture, http://optmix.irstea.fr/) experimental site, managed by Irstea and supported by the Centre-Val de Loire Region and the French National Forest Office (ONF). The work was financed by the French Ministry of the Environment through a grant to AM (Contract DEB-Irstea "Gestion des milieux et biodiversité" 20162017, action number 6). The experimental site belongs to the SOERE F-ORE-T network which is supported annually by Ecofor, Allenvi and the French national research infrastructure ANAEE-F (http://www.anaee-france.fr/fr/). We thank all the members of the OPTMix team for their technical 
help. We are grateful to the ONF and the French National Agency for Wildlife (ONCFS) for providing hunting statistics for the study site. We also address special thanks to Kamel Zouaydia and Jessica Maurize for their field work. We thank Victoria Moore for her assistance in correcting the English version of the manuscript.

\section{References}

Apollonio, M., Andersen, R., Putman, R., 2010. European ungulates and their management in the 21st century. Cambridge University Press, Cambridge.

Balandier, P., Sonohat, G., Sinoquet, H., Varlet-Grancher, C., Dumas, Y., 2006. Characterisation, prediction and relationships between different wavebands of solar radiation transmitted in the understorey of even-aged oak (Quercus petraea, Q. robur) stands. Trees 20, 363-370. https://doi.org/10.1007/s00468-006-0049-3

Bartels, S.F., Chen, H.Y.H., 2010. Is understory plant species diversity driven by resource quantity or resource heterogeneity? Ecology 91, 1931-1938. https://doi.org/10.1890/09-1376.1

Bates, D., Maechler, M., Bolker, B., Walker, S., 2014. Ime4: Linear mixed-effects models using Eigen and S4. http://CRAN.R-project.org/package=Ime4

Bobiec, A., Jaszcz, E., Wojtunik, K., 2011. Oak (Quercus robur L.) regeneration as a response to natural dynamics of stands in European hemiboreal zone. Eur. J. For. Res. 130, 785-797. https://doi.org/10.1007/s10342-010-0471-3

Bobiec, A., Reif, A., Öllerer, K., 2018. Seeing the oakscape beyond the forest: a landscape approach to the oak regeneration in Europe. Landsc. Ecol. 33, 513-528. https://doi.org/10.1007/s10980018-0619-y

Bond, W.J., Midgley, J.J., 2001. Ecology of sprouting in woody plants: the persistence niche. Trends Ecol. Evol. 16, 45-51. https://doi.org/10.1016/S0169-5347(00)02033-4 
Boulanger, V., Dupouey, J.-L., Archaux, F., Badeau, V., Baltzinger, C., Chevalier, R., Corcket, E., Dumas, Y., Forgeard, F., Mårell, A., Montpied, P., Paillet, Y., Picard, J.-F., Saïd, S., Ulrich, E., 2018. Ungulates increase forest plant species richness to the benefit of non-forest specialists. Glob. Chang. Biol. 24, e485-e495. https://doi.org/10.1111/gcb.13899

Bourdier, T., Cordonnier, T., Kunstler, G., Piedallu, C., Lagarrigues, G., Courbaud, B., 2016. Tree size inequality reduces forest productivity: An analysis combining inventory data for ten european species and a light competition model. PLoS ONE 11, e0151852. https://doi.org/10.1371/journal.pone.0151852

Buckley, D.S., Sharik, T.L., Isebrands, J.G., 1998. Regeneration of northern red oak: Positive and negative effects of competitor removal. Ecology 79, 65-78. https://doi.org/10.2307/176865

Burnham, K.P., Anderson, D.R., 1998. Model selection and interference: a pratical informationtheoretic approach. Springer-Verlag, New York.

Canadell, J., Lopez-Soria, L., 1998. Lignotuber reserves support regrowth following clipping of two Mediterranean shrubs. Funct. Ecol. 12, 31-38. https://doi.org/10.1046/j.13652435.1998.00154.x

Cooke, A.S., Lakhani, K.H., 1996. Damage to coppice regrowth by muntjac deer Muntiacus reevesi and protectin with electric fencing. Biol. Conserv. 75, 231-238. https://doi.org/10.1016/00063207(95)00070-4

Cordonnier, T., Kunstler, G., 2015. The Gini index brings asymmetric competition to light. Perspect. Plant Ecol. Evol. Syst. 17, 107-115. https://doi.org/10.1016/j.ppees.2015.01.001

Cromsigt, J.P.G.M., Kuijper, D.P.J., 2011. Revisiting the browsing lawn concept: Evolutionary Interactions or pruning herbivores? Perspect. Plant Ecol. Evol. Syst. 13, 207-215. https://doi.org/10.1016/j.ppees.2011.04.004

Cutini, A., Bongi, P., Chianucci, F., Pagon, N., Grignolio, S., Amorini, E., Apollonio, M., 2011. Roe deer (Capreolus capreolus L.) browsing effects and use of chestnut and Turkey oak coppiced areas. Ann. For. Sci. 68, 667-674. https://doi.org/10.1007/s13595-011-0072-4 
Danell, K., Bergström, R., Edenius, L., Ericsson, G., 2003. Ungulates as drivers of tree population dynamics at module and genet levels. For. Ecol. Manage. 181, 67-76. https://doi.org/10.1016/S0378-1127(03)00116-6

Decocq, G., Aubert, M., Dupont, F., Alard, D., Saguez, R., Wattez-Franger, A., Foucault, B.D., DelelisDusollier, A., Bardat, J., 2004. Plant diversity in a managed temperate deciduous forest: understorey response to two silvicultural systems. J. Appl. Ecol. 41, 1065-1079. https://doi.org/10.1111/j.0021-8901.2004.00960.x

Del Tredici, P., 2001. Sprouting in temperate trees: A morphological and ecological review. Bot. Rev. 67, 121-140. https://doi.org/10.1007/BF02858075

Dey, D.C., Gardiner, E.S., Schweitzer, C.J., Kabrick, J.M., Jacobs, D.F., 2012. Underplanting to sustain future stocking of oak (Quercus) in temperate deciduous forests. New For. 43, 955-978. https://doi.org/10.1007/s11056-012-9330-z

Dey, D.C., Jensen, R.G., 2002. Stump sprouting potential of oaks in Missouri Ozark forests managed by even- and uneven-aged silviculture. in: Shifley, S.R., Kabrick, J.M. (Eds.), Proceedings of the Second Missouri Ozark Forest Ecosystem Project Symposium: Post-treatment Results of the Landscape Experiment, St. Paul, MN: U.S. Dept. of Agriculture, Forest Service, North Central Forest Experiment Station, pp. 102-113.

Dey, D.C., Kabrick, J.M., Schweitzer, C.J., 2017. Silviculture to restore oak savannas and woodlands. J. For. 115, 202-211. https://doi.org/10.5849/jof.15-152

Dietze, M.C., Clark, J.S., 2008. Changing the gap dynamics paradigm: Vegetative regeneration control on forest response to disturbance. Ecol. Monogr. 78, 331-347. https://doi.org/10.1890/070271.1

Ducrey, M., Boisserie, M., 1992. Natural regrowth of holm oak coppice (Quercus ilex L.) following partial cuts. Ann. sci. for. 49, 91-109. https://doi.org/10.1051/forest:19920202 
Durand, Y., Brun, E., Merindol, L., Guyomarc'h, G., Lesaffre, B., Martin, E., 1993. A meteorological estimation of relevant parameters for snow models. Ann. Glaciol. 18, 65-71. https://doi.org/10.1017/S0260305500011277

Edenius, L., Ericsson, G., Kempe, G., Bergström, R., Danell, K., 2011. The effects of changing land use and browsing on aspen abundance and regeneration: A 50-year perspective from Sweden. J. Appl. Ecol. 48, 301-309. https://doi.org/10.1111/j.1365-2664.2010.01923.x

Espelta, J.M., Habrouk, A., Retana, J., 2006. Response to natural and simulated browsing of two Mediterranean oaks with contrasting leaf habit after a wildfire. Ann. For. Sci. 63, 441-447. https://doi.org/10.1051/forest:2006024

Fischer, H.S., 2015. On the combination of species cover values from different vegetation layers. Appl. Veg. Sci. 18, 169-170. https://doi.org/10.1111/avsc.12130

Forrester, J.A., Lorimer, C.G., Dyer, J.H., Gower, S.T., Mladenoff, D.J., 2014. Response of tree regeneration to experimental gap creation and deer herbivory in north temperate forests. For. Ecol. Manage. 329, 137-147. https://doi.org/10.1016/j.foreco.2014.06.025

Frerker, K., Sonnier, G., Waller, D.M., 2013. Browsing rates and ratios provide reliable indices of ungulate impacts on forest plant communities. For. Ecol. Manage. 291, 55-64. https://doi.org/10.1016/j.foreco.2012.11.041

Gardiner, E.S., Helmig, L.M., 1997. Development of water oak stump sprouts under a partial overstory. New For. 14, 55-62. https://doi.org/10.1023/a:1006502107495

Gill, R.M.A., 1992. A review of damage by mammals in north temperate forests: 3 . Impact on trees and forests. Forestry (Oxf.) 65, 363-388. https://doi.org/10.1093/forestry/65.4.363-a Götmark, F., 2007. Careful partial harvesting in conservation stands and retention of large oaks favour oak regeneration. Biol. Conserv. 140, 349-358. https://doi.org/10.1016/j.biocon.2007.08.018 
Götmark, F., 2013. Habitat management alternatives for conservation forests in the temperate zone: Review, synthesis, and implications. For. Ecol. Manage. 306, 292-307. https://doi.org/10.1016/j.foreco.2013.06.014

Götmark, F., Berglund, Å., Wiklander, K., 2005. Browsing damage on broadleaved trees in seminatural temperate forest in Sweden, with a focus on oak regeneration. Scand. J. For. Res. 20, 223-234. https://doi.org/10.1080/02827580510008383

Harrington, C.A., 1984. Factors influencing initial sprouting of red alder. Can. J. For. Res. 14, 357-361. https://doi.org/10.1139/x84-065

Hédl, R., Kopecký, M., Komárek, J., 2010. Half a century of succession in a temperate oakwood: from species-rich community to mesic forest. Divers. Distrib. 16, 267-276. https://doi.org/10.1111/j.1472-4642.2010.00637.x

Hewitt, D.G., 2011. Biology and management of white-tailed deer. CRC Press Taylor \& Francis Group, New York.

IUSS Working Group WRB, 2015. World Reference Base for Soil Resources 2014, update 2015. International soil classification system for naming soils and creating legends for soil maps. World Soil Resources Reports No. 106. FAO, Rome, p. 192.

Kaji, K., Saitoh, T., Uno, H., Matsuda, H., Yamamura, K., 2010. Adaptive management of sika deer populations in Hokkaido, Japan: theory and practice. Popul. Ecol. 52, 373-387. https://doi.org/10.1007/s10144-010-0219-4

Kay, S., 1993. Factors affecting severity of deer browsing damage within coppiced woodlands in the south of england. Biol. Conserv. 63, 217-222. https://doi.org/10.1016/0006-3207(93)90715-d Kelly, D.L., 2002. The regeneration of Quercus petraea (sessile oak) in southwest Ireland: a 25-year experimental study. For. Ecol. Manage. 166, 207-226. https://doi.org/10.1016/S03781127(01)00670-3 
Khan, M.L., Tripathi, R.S., 1986. Tree regeneration in a disturbed sub-tropical wet hill forest of northeast India: Effect of stump diameter and height on sprouting of four tree species. For. Ecol. Manage. 17, 199-209. https://doi.org/10.1016/0378-1127(86)90112-X

Kobe, R.K., Pacala, S.W., Silander, J.A., Canham, C.D., 1995. Juvenile tree survivorship as a component of shade tolerance. Ecol. Appl. 5, 517-532. https://doi.org/10.2307/1942040

Korboulewsky, N., Pérot, T., Balandier, P., Ballon, P., Barrier, R., Boscardin, Y., Emmanuelle, D.-R., Dumas, Y., Ginisty, C., Gosselin, M., Hamard, J.-P., Laurent, L., Mårell, A., NDiaye, A., Perret, S., Rocquencourt, A., Seigner, V., Vallet, P., 2015. OPTMix: Dispositif expérimental de suivi à long terme du fonctionnement de la forêt mélangée. Rendez-vous techniques 47, 60-70.

Kuiters, A.T., Slim, P.A., 2002. Regeneration of mixed deciduous forest in a Dutch forest-heathland, following a reduction of ungulate densities. Biol. Conserv. 105, 65-74. https://doi.org/10.1016/S0006-3207(01)00204-X

Latham, J., Staines, B.W., Gorman, M.L., 1996. The relative densities of red (Cervus elaphus) and roe (Capreolus capreolus) deer and their relationship in Scottish plantation forests. J. Zool. 240, 285-299. https://doi.org/10.1111/j.1469-7998.1996.tb05285.x

Leonardsson, J., Götmark, F., 2015. Differential survival and growth of stumps in 14 woody species after conservation thinning in mixed oak-rich temperate forests. Eur. J. For. Res. 134, 199209. https://doi.org/10.1007/s10342-014-0843-1

Lockhart, B.R., Chambers, J.L., 2007. Cherrybark oak stump sprout survival and development five years following plantation thinning in the lower Mississippi alluvial valley, USA. New For. 33, 183-192. https://doi.org/10.1007/s11056-006-9022-7

Lucas, T.C.D., Moorcroft, E.A., Freeman, R., Rowcliffe, J.M., Jones, K.E., 2015. A generalised random encounter model for estimating animal density with remote sensor data. Methods Ecol. Evol. 6, 500-509. https://doi.org/10.1111/2041-210X.12346 
Marcais, B., Desprez-Loustau, M.L., 2014. European oak powdery mildew: impact on trees, effects of environmental factors, and potential effects of climate change. Ann. For. Sci. 71, 633-642. https://doi.org/10.1007/s13595-012-0252-x

Martin, J.-L., Stockton, S., Allombert, S., Gaston, A., 2010. Top-down and bottom-up consequences of unchecked ungulate browsing on plant and animal diversity in temperate forests: lessons from a deer introduction. Biol. Invasions 12, 353-371. https://doi.org/10.1007/s10530-0099628-8

Marzano, R., Lingua, E., Garbarino, M., 2012. Post-fire effects and short-term regeneration dynamics following high-severity crown fires in a Mediterranean forest. iForest 5, 93-100. https://doi.org/10.3832ifor0612-005

Matula, R., Svatek, M., Kurova, J., Uradnicek, L., Kadavy, J., Kneifl, M., 2012. The sprouting ability of the main tree species in Central European coppices: implications for coppice restoration. Eur. J. For. Res. 131, 1501-1511. https://doi.org/10.1007/s10342-012-0618-5

Mayer, D.G., Butler, D.G., 1993. Statistical validation. Ecol. Model. 68, 21-32. https://doi.org/10.1016/0304-3800(93)90105-2

Merlin, M., Perot, T., Perret, S., Korboulewsky, N., Vallet, P., 2015. Effects of stand composition and tree size on resistance and resilience to drought in sessile oak and Scots pine. For. Ecol. Manage. 339, 22-33. https://doi.org/10.1016/j.foreco.2014.11.032

Moore, W.H., Johnson, F.M., 1967. Nature of deer browsing on hardwood seedlings and sprouts. J. Wildl. Manag. 31, 351-353. https://doi.org/10.2307/3798330

Moreno, J.M., Oechel, W.C., 1991. Fire intensity and herbivory effects on postfire resprouting of adenostoma-fasciculatum in southern california chaparral. Oecologia 85, 429-433. https://doi.org/10.1007/bf00320621

Müllerová, J., Pejcha, V., Altman, J., Plener, T., Dörner, P., Doležal, J., 2016. Detecting coppice legacies from tree growth. PLoS ONE 11, e0147205. https://doi.org/10.1371/journal.pone.0147205 
681

682

683

684

685

686

687

688

689

690

691

692

693

694

695

696

697

698

699

700

701

702

703

704

705

Nocentini, S., 2009. Structure and management of beech (Fagus sylvatica L.) forests in Italy. iForest 2, 105-113. https://doi.org/10.3832ifor0499-002

Nzunda, E.F., Griffiths, M.E., Lawes, M.J., 2014. Resource allocation and storage relative to resprouting ability in wind disturbed coastal forest trees. Evol. Ecol. 28, 735-749. https://doi.org/10.1007/s10682-014-9698-7

O'Hara, K.L., Berrill, J.P., 2010. Dynamics of coast redwood sprout clump development in variable light environments. J. For. Res. 15, 131-139. https://doi.org/10.1007/s10310-009-0166-0

Oliver, C.D., Burkhardt, E.C., Skojac, D.A., 2005. The increasing scarcity of red oaks in Mississippi River floodplain forests: Influence of the residual overstory. For. Ecol. Manage. 210, 393-414. https://doi.org/10.1016/j.foreco.2005.02.036

Paula, S., Ojeda, F., 2011. Response to recurrent disturbance in two co-occurring resprouter heath species: the ecological consequences of withstanding herbivores. Plant Ecol. 212, 2035-2045. https://doi.org/10.1007/s11258-011-9927-x

Perot, T., Mårell, A., Korboulewsky, N., Seigner, V., Balandier, P., 2017. Modeling and predicting solar radiation transmittance in mixed forests at a within-stand scale from tree species basal area. For. Ecol. Manage. 390, 127-136. https://doi.org/10.1016/j.foreco.2017.01.023

Pinheiro, J., Bates, D., DebRoy, S., Sarkar, D., R Development Core Team, 2011. nlme: Linear and Nonlinear Mixed Effects Models. http://CRAN.R-project.org/package=nlme

Pinheiro, J.C., Bates, D.M., 2000. Mixed-Effects Models in S and S-PLUS. Springer, New York.

Putman, R.J., Moore, N.P., 1998. Impact of deer in lowland Britain on agriculture, forestry and conservation habitats. Mammal. Rev. 28, 141-163. https://doi.org/10.1046/j.13652907.1998.00031.x

Pyttel, P.L., Fischer, U.F., Suchomel, C., Gärtner, S.M., Bauhus, J., 2013. The effect of harvesting on stump mortality and re-sprouting in aged oak coppice forests. For. Ecol. Manage. 289, 18-27. https://doi.org/10.1016/j.foreco.2012.09.046 
R Development Core Team, 2011. R: A language and environment for statistical computing. http://www.R-project.org/

Rooney, T., 2009. High white-tailed deer densities benefit graminoids and contribute to biotic homogenization of forest ground-layer vegetation. Plant Ecol. 202, 103-111. https://doi.org/10.1007/s11258-008-9489-8

Rowcliffe, J.M., Field, J., Turvey, S.T., Carbone, C., 2008. Estimating animal density using camera traps without the need for individual recognition. J. Appl. Ecol. 45, 1228-1236. https://doi.org/10.1111/j.1365-2664.2008.01473.x

Royo, A.A., Kramer, D.W., Miller, K.V., Nibbelink, N.P., Stout, S.L., 2016. The canary in the coal mine: Sprouts as a rapid indicator of browse impact in managed forests. Ecol. Indic. 69, 269-275. https://doi.org/10.1016/j.ecolind.2016.04.030

Rydberg, D., 2000. Initial sprouting, growth and mortality of European aspen and birch after selective coppicing in central Sweden. For. Ecol. Manage. 130, 27-35. https://doi.org/10.1016/S03781127(99)00187-5

Sands, B.A., Abrams, M.D., 2009. Effects of stump diameter on sprout number and size for three oak species in a pennsylvania clearcut. North. J. Appl. For. 26, 122-125. https://doi.org/10.1093/njaf/26.3.122

Schutz, A.E.N., Bond, W.J., Cramer, M.D., 2011. Defoliation depletes the carbohydrate reserves of resprouting Acacia saplings in an African savanna. Plant Ecol. 212, 2047-2055. https://doi.org/10.1007/s11258-010-9883-x

Sjölund, M.J., Jump, A.S., 2013. The benefits and hazards of exploiting vegetative regeneration for forest conservation management in a warming world. Forestry (Oxf.) 86, 503-513. https://doi.org/10.1093/forestry/cpt030

Sonohat, G., Balandier, P., Ruchaud, F., 2004. Predicting solar radiation transmittance in the understory of even-aged coniferous stands in temperate forests. Ann. For. Sci. 61, 629-641. https://doi.org/10.1051/forest:2004061 
Splichalova, M., Adamec, Z., Kadavy, J., Kneifl, M., 2012. Probability model of sessile oak (Quercus petraea (Matt.) Liebl.) stump sprouting in the Czech Republic. Eur. J. For. Res. 131, 16111618. https://doi.org/10.1007/s10342-012-0628-3

Svatek, M., Matula, R., 2015. Fine-scale spatial patterns in oak sprouting and mortality in a newly restored coppice. For. Ecol. Manage. 348, 117-123. https://doi.org/10.1016/j.foreco.2015.03.048

Tremblay, J.P., Huot, J., Potvin, F., 2007. Density-related effects of deer browsing on the regeneration dynamics of boreal forests. J. Appl. Ecol. 44, 552-562. https://doi.org/10.1111/j.13652664.2007.01290.x

Van Bloem, S.J., Murphy, P.G., Lugo, A.E., 2007. A link between hurricane-induced tree sprouting, high stem density and short canopy in tropical dry forest. Tree Physiol. 27, 475-480. https://doi.org/10.1093/treephys/27.3.475

Vesk, P.A., Westoby, M., 2004. Sprouting ability across diverse disturbances and vegetation types worldwide. J. Ecol. 92, 310-320. https://doi.org/10.1111/j.0022-0477.2004.00871.x

Waller, D.M., Alverson, W.S., 1997. The white-tailed deer: a keystone herbivore. Wildl. Soc. Bull. 25, 217-226.

Weigel, D.R., Peng, C.-Y.J., 2002. Predicting stump sprouting and competitive success of five oak species in southern Indiana. Can. J. For. Res. 32, 703-712. https://doi.org/10.1139/x02-042

Xue, Y., Zhang, W., Zhou, J., Ma, C., Ma, L., 2013. Effects of stump diameter, stump height, and cutting season on Quercus variabilis stump sprouting. Scand. J. For. Res. 28, 223-231. https://doi.org/10.1080/02827581.2012.723742 

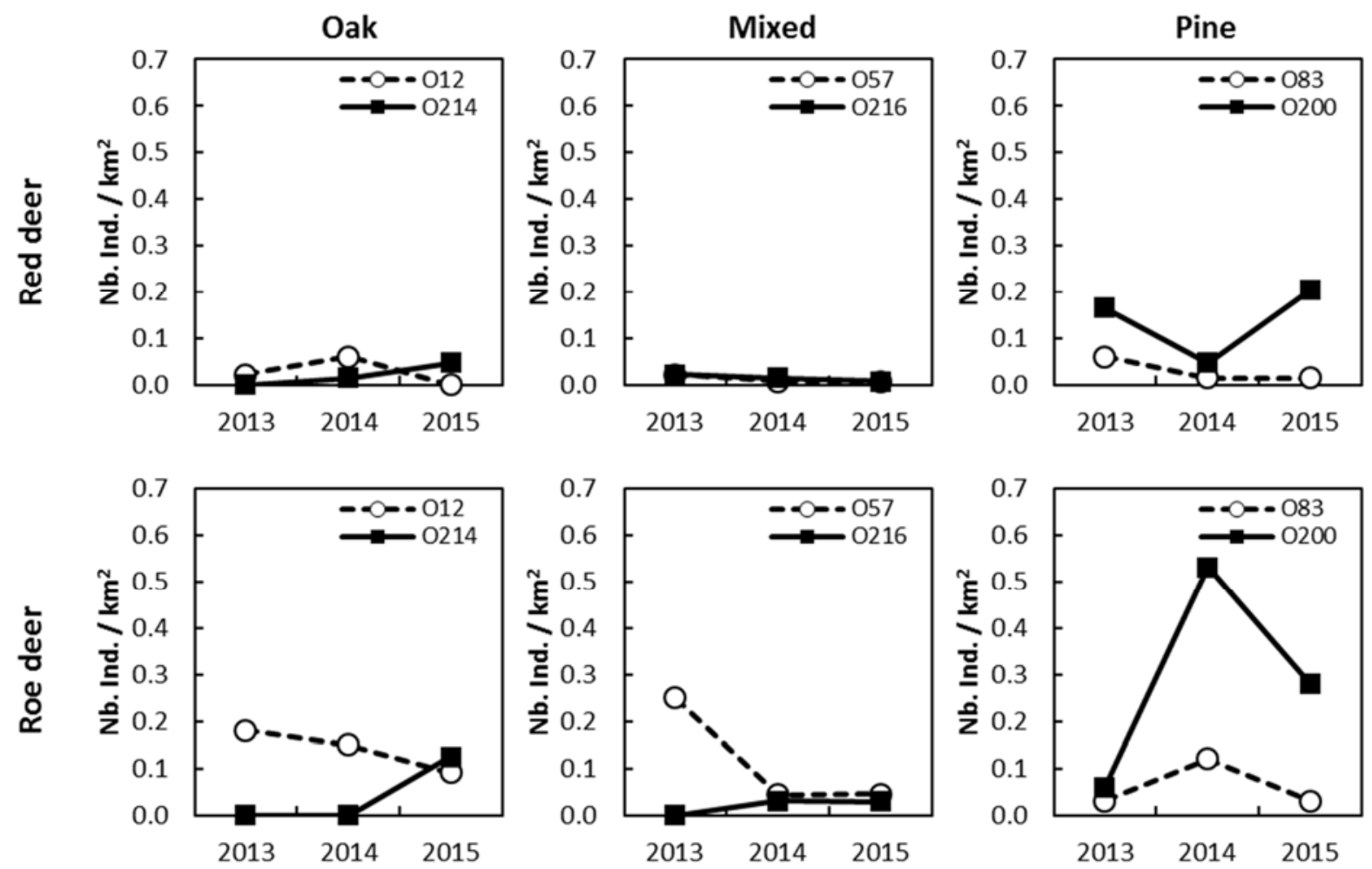

Supplementary Figure 1. Estimated local density of red (Cervus elaphus L.) and roe (Capreolus

capreolus L.) deer at the study plots. A random encounter model (REM) was used to estimate local

densities (Rowcliffe et al., 2008; Lucas et al., 2015). Camera trapping was performed during three

four-week periods: February-March, May-June and November-December. During each four-week

period, a single camera per unfenced study plot was left in place for 6 consecutive days at each period. The sensor detection zone parameters $r$ and $\theta$ were estimated at $13.7 \mathrm{~m}$ and 45 degrees, 
769 hunting pressure corresponds to a harvesting level that has maintained a relatively stable deer

770 population for the last ten years.

771 
(a)

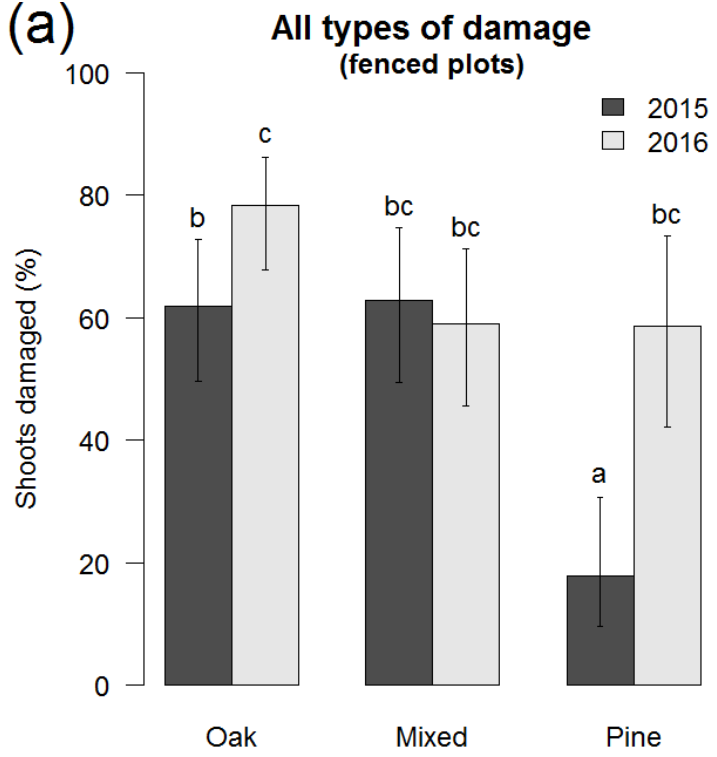

(b) Powdery mildew/frost

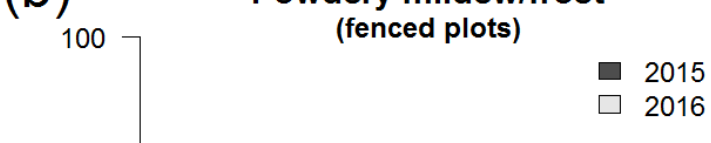

772


773

774

Supplementary Figure 2. Observed damage other than deer browsing on tagged shoots in fenced

775 plots: (a) all types of damage excluding deer browsing, (b) powdery mildew or frost damage, (c)

776 browsing by rodents or lagomorphs, (d) parasitic attacks such as gall formation and plant tissue

777 losses due to insect herbivory and (e) vegetation competition. All shoots in the unfenced plots were

778 browsed by deer and other types of damages were negligible.

779 


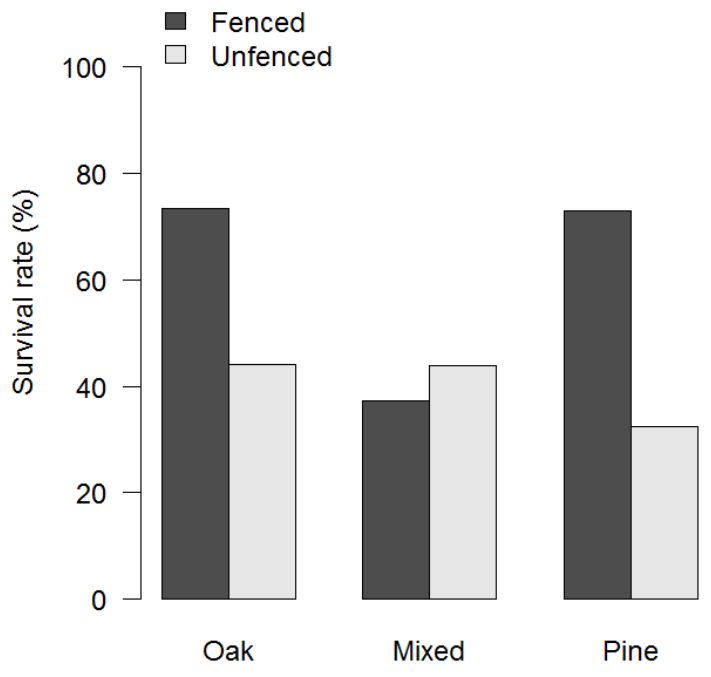

781

782 Supplementary Figure 3. Survival rate of oak stumps in late winter 2016 in fenced and unfenced plots

783 based on observed values in monospecific and mixed sessile oak/Scots pine stands.

784 


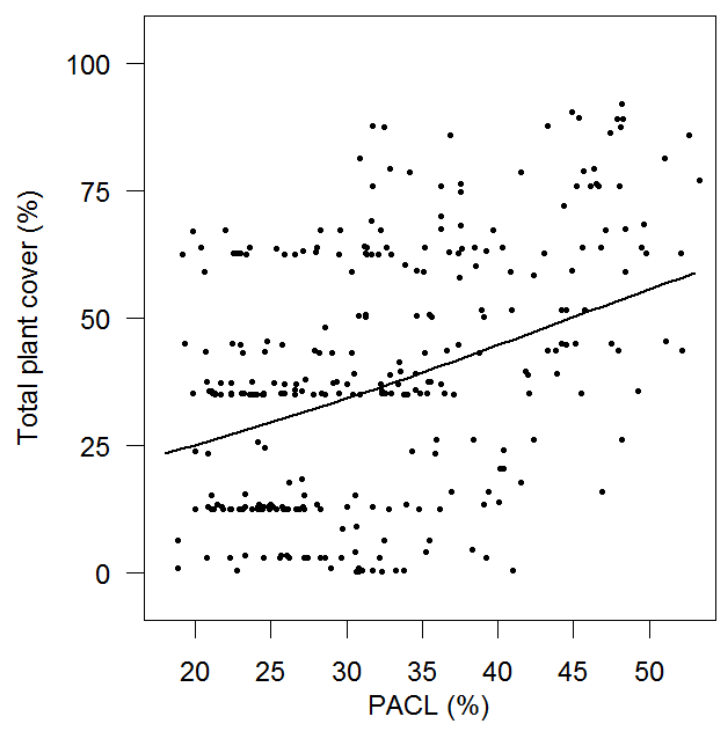

786 Supplementary Figure 4. Observed correlation pattern between total plant cover and PACLEST. Total

787 plant cover is continuous data bounded between $0 \%$ and $100 \%$. We therefore used a Beta error

788 distribution (Chen et al., 2006; Chen et al., 2008; Damgaard, 2014) belonging to the glmmadmb

789 function of the gImmADMB package (Fournier et al. 2012, Skaug et al. 2016).

790 
791 Supplementary Table 1. Summary statistics of models predicting annual growth in length (LENGTH) of 792 the five most vigorous shoots per sessile oak stump in mono-specific and mixed sessile oak/Scots 793 pine stands

\begin{tabular}{|c|c|c|c|c|c|c|c|c|c|}
\hline Model $^{\S}$ & $\mathrm{N}$ & df & $\sigma_{\text {site }}$ & $\sigma_{\text {plot }}$ & $\sigma_{\text {stump }}$ & $\sigma_{\text {resid. }}$ & $\mathrm{AICc}$ & $\mathrm{EF}_{\text {full }}$ & $\mathrm{EF}_{\mathrm{fix}}$ \\
\hline \multicolumn{10}{|l|}{ Null model } \\
\hline LENGTH = INTERCEPT & 563 & 10 & $<0.001$ & 381.9 & 38.4 & 473.4 & 4961.8 & 0.48 & \\
\hline \multicolumn{10}{|c|}{ Reference model (experimental design) } \\
\hline LENGTH $=\mathrm{C}+\mathrm{H}+\mathrm{C} \times \mathrm{H}$ & 563 & 15 & $<0.001$ & 17.9 & 37.0 & 474.2 & 4934.8 & 0.47 & 0.37 \\
\hline \multicolumn{10}{|c|}{ Diameter at breast height of the parent tree $\left(D B H_{\text {parent }}\right)$ as covariate } \\
\hline \multicolumn{10}{|l|}{ LENGTH $=\mathrm{C}+\mathrm{H}+\mathrm{C} \times \mathrm{H}+\mathrm{DBH}_{\text {parent }}+\mathrm{H}$} \\
\hline & 563 & 17 & $<0.001$ & 26.4 & 34.7 & 471.3 & 4934.5 & 0.47 & 0.38 \\
\hline \multicolumn{10}{|l|}{$\times \mathrm{DBH}_{\text {parent }}$} \\
\hline \multicolumn{10}{|c|}{ Percentage of above-canopy light (PACL $\left.L_{E S T}\right)$ as covariate } \\
\hline \multicolumn{10}{|l|}{ LENGTH $=\mathrm{C}+\mathrm{H}+\mathrm{PACL}_{\mathrm{EST}}+\mathrm{C} \times$} \\
\hline & 563 & 17 & $<0.001$ & 11.5 & 40.0 & 470.8 & 4932.5 & 0.48 & 0.38 \\
\hline \multicolumn{10}{|l|}{$\mathrm{PACL}_{\text {EST }}+\mathrm{H} \times \mathrm{PACL}_{\mathrm{EST}}$} \\
\hline \multicolumn{10}{|l|}{ LENGTH $=\mathrm{C}+\mathrm{H}+\mathrm{PACL}_{\text {EST }}+\mathrm{C} \times \mathrm{H}+\mathrm{C}$} \\
\hline & 563 & 19 & $<0.001$ & 11.4 & 39.8 & 471.7 & 4933.7 & 0.48 & 0.38 \\
\hline \multicolumn{10}{|l|}{$\times$ PACLEST $+\mathrm{H} \times$ PACLEST } \\
\hline \multicolumn{10}{|c|}{ Total plant cover (COVER $\left.R_{\text {TOT }}\right)$ as covariate } \\
\hline LENGTH $=\mathrm{C}+\mathrm{H}+\mathrm{C} \times \mathrm{H}+$ COVER $_{\text {TOT }}$ & 563 & 16 & $<0.001$ & 13.8 & 37.4 & 476.0 & 4934.7 & 0.47 & 0.37 \\
\hline \multicolumn{10}{|l|}{ LENGTH $=\mathrm{C}+\mathrm{H}+\mathrm{C} \times \mathrm{H}+$ COVERTOT +} \\
\hline & 563 & 18 & $<0.001$ & 12.4 & 35.5 & 475.3 & 4934.8 & 0.46 & 0.37 \\
\hline \multicolumn{10}{|l|}{$\mathrm{C} \times$ COVERTOT } \\
\hline \multicolumn{10}{|l|}{ LENGTH $=\mathrm{C}+\mathrm{H}+\mathrm{C} \times \mathrm{H}+$ COVERTOT +} \\
\hline \multicolumn{10}{|l|}{$\mathrm{H} \times \mathrm{COVER}_{\text {TOT }}$} \\
\hline \multicolumn{10}{|l|}{ LENGTH $=\mathrm{C}+\mathrm{H}+\mathrm{C} \times \mathrm{H}+$ COVERTOT +} \\
\hline & 563 & 21 & $<0.001$ & 10.5 & 36.4 & 476.4 & 4936.1 & 0.47 & 0.38 \\
\hline $\mathrm{H} \times \mathrm{COVER}_{\text {TOT }}+\mathrm{C} \times \mathrm{H} \times \mathrm{COVER}_{\text {TOT }}$ & & & & & & & & & \\
\hline
\end{tabular}

${ }^{\S} \mathrm{A}$ first model was fitted to test for differences related to the experimental design (reference model), where stand composition $(\mathrm{C})$, herbivore exclusion $(\mathrm{H})$ and their interaction were fixed terms. The random term was composed of site, study plot nested within site and stump nested within study plot in order to take into account the nested sampling design (paired fenced-unfenced plots). Covariates were added to the model to see whether they improved model fitting or could replace one of the fixed terms in the first model. Model selection was based on the Akaike information criterion adjusted for small sample size (AICC). Only the best models with a difference in AICC of less than 2 are displayed. The most parsimonious models are shown in bold. 


\section{Supplementary references}

Chen, J., Shiyomi, M., Bonham, C.D., Yasuda, T., Hori, Y., Yamamura, Y., 2008. Plant cover estimation based on the beta distribution in grassland vegetation. Ecol. Res. 23, 813-819. https://doi.org/10.1007/s11284-007-0443-3

Chen, J., Shiyomi, M., Yamamura, Y., Hori, Y., 2006. Distribution model and spatial variation of cover in grassland vegetation. Grassl. Sci. 52, 167-173. https://doi.org/10.1111/j.1744$697 X .2006 .00065 . X$

Damgaard, C., 2014. Estimating mean plant cover from different types of cover data: a coherent statistical framework. Ecosphere 5:1-7. https://doi.org/10.1890/ES13-00300.1

Fournier, D.A., Skaug, H.J., Ancheta, J., lanelli, J., Magnusson, A., Maunder, M., Nielsen, A. and Sibert, J. 2012. AD Model Builder: using automatic differentiation for statistical inference of highly parameterized complex nonlinear models. Optim. Methods Softw. 27, 233-249. https://doi.org/10.1080/10556788.2011.597854.

Lucas, T.C.D., Moorcroft, E.A., Freeman, R., Rowcliffe, J.M., Jones, K.E., 2015. A generalised random encounter model for estimating animal density with remote sensor data. Methods Ecol. Evol. 6, 500-509. https://doi.org/10.1111/2041-210X.12346

Pellerin, M., Picard, M., Saïd, S., Baubet, E., Baltzinger, C., 2016. Complementary endozoochorous long-distance seed dispersal by three native herbivorous ungulates in Europe. Basic Appl. Ecol. 17, 321-332. https://doi.org/10.1016/j.baae.2016.01.005

Rowcliffe, J.M., Field, J., Turvey, S.T., Carbone, C., 2008. Estimating animal density using camera traps without the need for individual recognition. J. Appl. Ecol. 45, 1228-1236. https://doi.org/10.1111/j.1365-2664.2008.01473.x

Skaug, H., Fournier, D., Bolker, B., Magnusson, A., Nielsen, A. 2016. Generalized Linear Mixed Models using 'AD Model Builder'. R package version 0.8.3.3. 